\title{
Tanárszakos hallgatók angolnyelv-tanulási és online olvasásistratégia-használata közötti összefüggések
}

\author{
Habók Anita* és Magyar Andrea**
}

DOI: $10.21549 /$ NTNY.32.2021.1.5

Napjainkban az idegen nyelvek tanulása, elsajátítása, az idegen nyelvhez kötődő információszerzés gyakran online színtéren valósul meg, amelynek feltétele, hogy a nyelvtanulók rendelkezzenek az idegen nyelven elérhető információk értelmezéséhez és feldolgozásához szükséges szintú idegen nyelvi olvasási készségekkel és online olvasási stratégiákkal. Kutatásunk célja annak feltérképezése, hogy az egyetemi hallgatók milyen mértékben használják a digitális térben a különböző információk szerzését segitő online olvasási stratégiákat, valamint, hogy milyen kapcsolat van a hallgatók nyelvtanulási stratégiáinak és online olvasási stratégiáinak használata között. A nyelvtanulási stratégiák használatának mérésére Oxford (1990) Strategy Inventory for Language Learning (SILL) kérdöívét, az online olvasási stratégiák vizsgálatára Anderson (2003) Online Survey of Reading Strategies (OSORS) kérdőivét alkalmaztuk. Az eredmények mindkét kérdőiv esetében mérsékelt stratégiahasználatot jeleztek. A nyelvtanulási stratégiák közül a metakognitiv stratégiák használata volt a legjellemzőbb, míg az online olvasási stratégiák közül a problémamegoldó stratégiatípus volt a leggyakrabban használt. A különböző nyelvtanulási és olvasási stratégiák között mindenütt szignifikáns kapcsolatot detektáltunk, és eredményeink megerösítették többdimenziós modellünk müködóképességét, amely szerint a nyelvtanulási stratégiák összességében nem, azonban bizonyos faktoraik szignifikáns hatást gyakorolnak az online olvasási stratégiahasználatra. A nyelvtanulási stratégiák közül a memória, a kompenzáló és a kognitív stratégiák hatása a legjelentősebb, és az átfogó olvasási stratégiák központi szerepe figyelhető meg. Kutatásunk felhivta a figyelmet a stratégiahasználat tanításának fontosságára.

Kulcsszavak: nyelvtanulási stratégia, online olvasás, kérdőív, modellfejlesztés

\section{Bevezetés}

A nyelvtanulás szerepe egyre jobban felértékelődik, mivel a globalizálódó világban egyre több olyan tartalom érhető el, melynek elolvasásának és megértésének csak a nyelvtudás hiánya szab határt. Ezáltal az iskolai nyelvtanulás és nyelvtanítás szerepe is megerősödik (Oxford, 2017). A hatékonyságnak egyik fontos faktora, hogy a tanulók milyen stratégiákat használnak a tanulásukban, tudják-e értékelni és megfogalmazni maguk számára azt, hogy hogyan tanulnak a leghatékonyabban (Doró, Habók \& Magyar, 2018; Habók \& Magyar, 2018a, 2018b). A nyelvtanulási stratégiák ahhoz segítenek hozzá, hogy a nyelvtanulás könnyebben és hatéko nyabban történjen, használatuk a különböző szituációk esetében transzferálható legyen, a tanuló felismerje használatuk relevanciáját és a tanulási feladattól és céltól függetlenül használják a stratégiákat (Oxford, 2017; Magyar \& Habók, 2018). Azok a tanulók, akik felülvizsgálják, hogy melyik tanulási helyzetben melyik stratégiát

* Egyetemi docens, SZTE Neveléstudományi Intézet, e-mail: habok@edpsy.u-szeged.hu

** Igazgató, Domonkos Nővérek Liszt Ferenc Ének-zenei Általános Iskolája, e-mail: mandrea@edu.u-szeged.hu 
választják, hatékonyságukat figyelemmel kísérik, sikeresebb önszabályozó tanulóvá válnak (Habók \& Magyar, 2018b).

Az online tanulás elterjedésével az információk célzott keresése, kiválogatása és megértése egyre gyakrabban kapcsolódik online színtérhez. Nemcsak a szabadidős tevékenységben jelenik meg az online eszközök használata, de a tanulásnak és nyelvtanulásnak is hatékony eszköze (Coiro \& Dobler, 2007; Coiro, 2012; Cho \& Afflerbach, 2017). Az online térben történő eligazodás olyan stratégiák használatát követeli meg, amelyek nagyban különböznek az eddigi információszerző- és feldolgozó stratégiáktól. A különbségek egyrészt abból adódnak, hogy az interneten elérhető szövegek gyakran nem lineárisak, inkább interaktívak az ún. hiperlinkeknek, multimédiás szövegeknek köszönhetően. Ezek az elágazások és többszintű információk jellemzően nem a részletes, lineáris olvasást követelik meg az olvasótól, hanem az áttekintő, információkereső, beleolvasó stratégiákat preferálják, amelyekhez számos magasabb rendű gondolkodási művelet aktivizálása szükséges (Coiro \& Dobler, 2007; Coiro, 2012; Cho \& Afflerbach, 2017).

Annak ellenére, hogy az olvasási stratégiák vizsgálata intenzíven kutatott terület, az idegen nyelvi olvasási stratégiák feltárására kevesebb hangsúly kerül. Ezen belül is viszonylag a legkevésbé kutatott terület az online térben való olvasási stratégiák használata, amely terület feltárásának jelenlegi digitális világunkban egyre na gyobb a jelentősége. Kutatásunk célja annak feltárása, hogy az egyetemi hallgatók körében milyen szintű a különböző nyelvtanulási stratégiák használata, milyen szinten használnak a digitális térben a különböző online információk szerzését segítő online olvasási stratégiákat, valamint, hogy milyen kapcsolat van a nyelvtanulási stratégiák használata és az online olvasási stratégiák használata között.

\section{Elméleti háttér}

\section{Nyelvtanulási stratégiák}

A nyelvtanulási stratégiák kutatása a hetvenes években kezdődött, amelynek első fázisában Rubin (1975) azt kezdte el tanulmányozni, hogy a sikeres nyelvtanulónak milyen képességekkel kell rendelkezni a hatékonyság biztosításához (Habók \& Magyar, 2018a). A következő jelentős változás a '90-es évektől kezdődött, amikor Oxford $(1990,2003,2017)$ azt kezdte el feltérképezni, hogy mely faktorok befolyásolják a nyelvtanulást. Taxonómiájának alapját két stratégiacsoport alkotja, a direkt és indirekt stratégiák. A direkt stratégiák három stratégiatípust foglalnak magukba, a memória stratégiákat, melyek az információk befogadásával, szervezésével és tárolásával foglalkoznak; a kognitív stratégiákat, melyek az információk feldolgozásának mentális folyamatait mutatják; és a kompenzáló stratégiákat, melyek a hiányzó információk helyettesítését szolgálják. A másik csoport, az indirekt stratégiáké, melyek szintén három stratégiát fednek le, ezek a metakognitiv stratégiák, melyek a stratégiák tervezésére, monitorozására és felülvizsgálatára vonatkoznak; az affektív stratégiák, melyek a nyelvtanuláshoz kapcsolódó érzelmek feltárását célozzák; és a szociális stratégiák, melyek az idegen nyelvet használókhoz vagy anyanyelvi beszélókhöz kapcsolódó kommunikációs helyzetekre reflektálnak. Oxford kutatásai nyomán kidolgozta a Strategy Inventory for Language Learning (SILL, Oxford, 1990, 2003) címú kérdőívet, mely azóta is az egyik leggyakrabban használt mérőeszköz. Később, a kérdőivet ért kritikák hatására és az új önszabályozott tanuláselméletekre támaszkodva, Oxford átdolgozta taxonómiáját, részben megtartva egyes részeit, részben az önszabályozott tanuláshoz adaptálva (Dörnyei, 2005; Tseng, Dörnyei \& Schmitt, 2006). Új, kibővített taxonómiájában a nyelvtanulási stratégiákat három fő dimenzióra tagolta: a kognitív, az affektív és a szociokulturális-interaktív dimenziókra. Ezeket a stratégiákat a metakognitív, a metaaffektív, és a metaszociokulturális-interaktív területek önszabályozott stratégiái irányítják (Oxford, 2017; Habók \& Magyar, 2018b). 


\section{Online olvasási stratégiák}

Az olvasási képességek meghatározó szerepet töltenek be a nyelvtanulásban. Az idegen nyelvi olvasást számos tényező befolyásolja, ezek közül az egyik legjelentősebb az anyanyelven történő olvasási képességek fejlettsége, amely általában fejlettebb az idegen nyelvi képességeknél. Meghatározó továbbá a szókincs, az idegen nyelvtani formulák ismeretének hiánya, vagy a kulturális különbségekben való járatlanság (Grabe, 2009). További jelentős befolyásoló tényező az olvasásistratégia-használat, amelynek vizsgálata az utóbbi években vált hangsúlyossá. Mokhtari és Sheorey (2002) taxonómiája megkülönböztette az átfogó, a problémamegoldó és az olvasást segítő stratégiákat. Az átfogó stratégiák a tanulók megértési folyamatait támogatják az olvasás alatt, a problémamegoldó stratégiák az olvasás során felmerülő nehézségek leküzdésében játszanak szerepet, míg az olvasást segítő stratégiák a szövegértéshez felhasznált támogató eszközöket és technikákat foglalják magukba. E taxonómián alapuló, általuk kifejlesztett Survey Of Reading Strategies (SORS) kérdőív az egyik leggyakrabban használt mérőeszköz az olvasási stratégiák vizsgálatára. A kérdőívet később Anderson (2003) kiegészítette az online tanulási környezethez igazítva és hasonló struktúrával megalkotta az Online Survey Of Reading Strategies (OSORS) kérdőívet. A kérdőív számos kutatás alapját képezte (Mokhtari \& Sheorey, 2002; Poole, 2010; Takallou, 2011; Ahmadian \& Pasand, 2017). A kutatások eredményei alapján nem rajzolódott ki egy-egy tipikusan használt stratégia, egyes kutatásokban a globális (Ahmadian \& Pasand, 2017), míg másokban a problémamegoldó stratégia (Anderson, 2003; Omar, 2014) preferenciája mutatkozott.

Magyarországon az olvasási stratégiák vizsgálata gyakran kutatott téma, azonban ritkábban kerül a hangsúly az idegen nyelvi olvasási stratégiák elemzésére. Magyar és Habók (2018) angol mint idegen nyelvből az olvasásistratégia-használat és az olvasási teszteredmény közötti összefüggéseket kutatta felső tagozatos tanulók részvételével online kérdőív és teszt használatával. Eredményeik arra mutattak rá, hogy a vizsgálatban részt vevők a metakognitiv stratégiákat használták a leggyakrabban. Habók, Magyar és Nagy-Pál (2018) az olvasás előtti, alatti és utáni stratégiahasználatot vizsgálta felső tagozatos tanulók körében, míg Habók és Magyar (2018a, 2018b, 2019) az iskolai eredmény, stratégiahasználat és attitúd közötti összefüggéseket vizsgálta. Eredményeik szerint az angol nyelvi attitűd szignifikáns hatással van az olvasási stratégiákra.

Ezek a kutatások azonban a nyelvtanulási stratégiákat az olvasási stratégiákkal való összefüggésükben vizsgálják ugyan, azonban a nyelvtanulási stratégiák idegen nyelvi online olvasási stratégiákkal való együttes vizs gálatára és kölcsönös hatásuknak az elemzésére nem került még sor. A két terület külön-külön történő vizsgá lata alapján megállapítható, hogy a nyelvtanulási stratégiák és az olvasási stratégiák szoros kapcsolatban vannak egymással, feltételezésünk szerint a nyelvtanulási stratégiák és az online olvasási stratégiák között is szignifikáns összefüggés mutatható ki. Kutatásunk fő célja az összefüggések irányának és erősségének megállapítása.

\section{Kutatási kérdések}

Kutatásunk középpontjába a következő kérdések kerültek: (1) Milyen gyakorisággal használják az egyetemi hallgatók az angol mint idegen nyelvi tanulási stratégiákat és milyen gyakorisággal (2) az online olvasási stratégiákat. Továbbá választ kerestünk arra, hogy (3) milyen kapcsolatok tárhatók fel az angol mint idegen nyelvi ta nulási stratégiák és az online olvasási stratégiák között. 


\section{Módszerek}

\section{Minta}

Kutatásunkba 250 tanárszakos egyetemi hallgatót vontunk be, közülük 249 fő adatait elemeztük ( $\mathrm{n}_{\text {férf }}=60$ (24\%), $\left.\mathrm{n}_{\mathrm{nŏ}}=189(76 \%)\right)$. A hallgatók mindegyike rendelkezik nyelvtanulási tapasztalattal, 15 hallgató kivételével második nyelvet is tanulnak az angol nyelven kívül. A leggyakrabban választott idegen nyelv a német, a francia, a spanyol, az olasz, az orosz vagy a szerb. Az angolnyelv-tanulással eltöltött éveket az 1. táblázat mutatja.

\begin{tabular}{|lc|}
\hline \multicolumn{1}{|c|}{ Nyelvtanulás évei } & Hallgatók \\
\hline Maximum -2 évig & 15 \\
\hline 3-5 év & 30 \\
\hline 6-8 év & 37 \\
9-11 év & 50 \\
\hline 12-14 év & 61 \\
\hline Több, mint 15 év & 55 \\
\hline
\end{tabular}

1. táblázat: Az angol mint idegen nyelv tanulásának évei

A táblázatból kiderül, hogy kezdő nyelvtanulók aránya a legalacsonyabb, és összesen 45 olyan hallgató van, aki 5 éve, vagy annál rövidebb ideje tanul angolt. A minta 55 résztvevője több, mint 15 éves nyelvtanulási tapasztalattal rendelkezik. A 12 vagy annál több éve angolt tanulók száma 116, mely a minta feléhez közelít.

\section{Mérőeszközök}

A kutatásban két mérőeszközt használtunk. Először a hallgatók kitöltötték Oxford Strategy Inventory for Lan guage Learning (SILL) kérdőívének magyar nyelvű változatát, amelyet Doró és Habók (2013) fordítása alapján adaptáltuk. A kérdőív korábbi eredmények alapján megbízható eszköznek bizonyult Oxford (1990) kutatásaiban is (Cronbach- $\alpha=0,91-0,94)$ és magyar mintán is (Cronbach- $\alpha=0,91$; Doró \& Habók, 2013). Az 50 itemes kérdőívben hatféle stratégiahasználatának álításaira adtak választ a hallgatók, amelyek (1) a memória (9 item), például „Gyakran átnézem az angolórai anyagot.”; (2) a kognitív (14 item), például „Többször elmondom vagy leírom az új angol szavakat."; (3) a kompenzáló (6 item), például „Ha nem jut eszembe egy szó beszélgetés közben, elmutogatom.”; (4) a metakognitív (9 item), például „Igyekszem minél több lehetőséget találni az angol nyelv használatára."; (5) az affektív (6 item), például „Bátorítom magam, hogy angolul beszéljek még akkor is, amikor félek attól, hogy hibázom.”; és (6) a szociális stratégiák (6 item), például „Ha valamit nem értek angolból, megkérem a beszélgetőpartneremet, hogy lassítson, vagy mondja el még egyszer." A válaszok megadása ötfokú Likert-skálán történt. A válaszok átlaga alapján különbözteti meg a kérdőív az alacsony (2,4 alatti), a mérsékelt (2,5 és 3,4 közötti), valamint a magas szintű (3,5 feletti) stratégiahasználókat (Oxford, 1990).

Az online olvasási stratégiák vizsgálatát az Anderson (2003) által fejlesztett Online Survey of Reading Strategies (OSORS) kérdőívvel végeztük. A vizsgálatunk résztvevői az angol online olvasási szokásokra adaptált változatot töltötték ki. A jelen kutatásban használt kérdőív 38 itemet tartalmaz, és az itemek három kategóriába sorolhatóak: (1) globális vagy átfogó olvasási stratégiák (18 item), például „Átfutom az online szöveget, hogy képet kapjak arról, hogy megfelel-e az elképzeléseimnek, mielőtt elhatározom, hogy elolvasom."; (2) probléma- 
megoldó stratégiák (11 item), például „Időről időre megállok, és elgondolkodom, hogy mit olvastam online.”; és (3) olvasást támogató stratégiák (9 item), például „Online olvasás alatt a jegyzetelés segít megérteni, amit olva sok." A kérdőívben adott válaszokat szintén ötfokú Likert-skálán kellett bejelölni a résztvevőknek. 2,4 vagy az alatti átlag alacsony szintű stratégiahasználatot jelöl, 2,5 és 3,4 között mérsékelt, 3,5 feletti átlag magas szintű stratégiahasználatra utal (Anderson, 2003). A teljes kérdőív reliabilitása Anderson (2003) vizsgálatában 0,92-es Cronbach- $\alpha$ értéket mutatott, az átfogó olvasási stratégiákra nézve Cronbach- $\alpha=0,77$, a problémamegoldó stratégiák esetében Cronbach- $\alpha=0,64$, és az olvasást támogató stratégiák területén Cronbach- $\alpha=0,69$ volt.

\section{Kutatástervezés}

A kutatás az etikai előírások betartásával történt. A hallgatókat biztosítottuk a kutatásban való részvétel anonimitásáról, informáltuk őket, hogy válaszaikat bizalmasan kezeljük, harmadik félnek nem adjuk ki. A résztvevők e-mailes értesítést kaptak a kutatásban történő részvétel lehetőségéről, továbbá a kutatás céljáról. A részvétel önkéntes volt, az elektronikusan elküldött link megnyitása után a hallgatók további részletes információt kaptak a kutatás témájáról, és az adatfelvétel körülményeiről. A kutatásba való beleegyező szándékuk megadása után kitölthették az online mérőeszközöket a kitöltésre rendelkezésre álló időintervallumban, amire egy hónapot biztosítottunk.

\section{Eljárások}

Az első kutatási kérdésünk megválaszolásához az SPSS Statistics 23.0 programot használtuk a reliabilitás, az átlagok és a szórások megállapítása céljából. Az átlagok közötti szignifikanciaszintet egymintás t-próbával vizsgáltuk. A második kutatási kérdésünkhöz egy feltételezett modellt alkottunk, mely az angolnyelv-tanulási stratégiák és az online olvasási szokások közötti kapcsolatot és hatásokat mutatja. A modell múködésének igazolásához megvizsgáltuk a területek közötti kapcsolatok erősségét Pearson-féle korrelációanalízissel, majd a modellünk múködésének igazolására útvonalelemzést használtunk, melyet IBM SPSS AMOS 23.0 programmal végeztünk. A modell illeszkedésének vizsgálatára a Chi-négyzet, a TLI (Tucker-Lewis Index), a CFI (Comparative Fit Index), NFI (Normed Fit Index), valamint az RMSEA (Root Mean Square Error of Approximation) mutatókat számítottuk ki. Míg a TLI-, a CFI- és az NFI-indexek esetében 0,9 fölötti, addig az RMSEA-index esetében 0,06 alatti értéket tekintettünk megfelelőnek (Kline, 2015). A modellben a változók egymásra gyakorolt szignifikáns hatását nyilakkal reprezentáltuk.

\section{Eredmények}

\section{Leíró statisztika}

Megvizsgáltuk a két kérdőív kategóriáinak megbízhatóságát. A nyelvtanulási stratégiák esetében a legmagasabb reliabilitást a metakognitiv stratégiahasználat esetében találtuk (Cronbach- $\alpha=0,88$ ), míg a legalacsonyabb értéket az affektív stratégiahasználat esetében regisztráltuk (Cronbach- $\alpha=0,56$ ).

Az online olvasási kérdőiv esetében az átfogó online olvasási stratégiák használatánál találtuk a legmagasabb Cronbach- $a$ értéket (Cronbach- $\alpha=0,85)$. A legalacsonyabbat az olvasást támogató stratégiák területén (Cronbach- $\alpha=0,75)$. 


\begin{tabular}{|c|c|c|c|c|}
\hline Kérdőív & Kategóriák & $\begin{array}{l}\text { Reliabilitás } \\
(\text { Cronbach- } \alpha)\end{array}$ & Átlag (M) & Szórás (SD) \\
\hline \multirow{6}{*}{ SILL } & Memória & 0,58 & 2,95 & 0,53 \\
\hline & Kognitív & 0,80 & 3,21 & 0,62 \\
\hline & Kompenzáló & 0,58 & 3,13 & 0,62 \\
\hline & Metakognitív & 0,88 & 3,34 & 0,82 \\
\hline & Affektív & 0,56 & 2,47 & 0,62 \\
\hline & Szociális & 0,80 & 3,13 & 0,85 \\
\hline \multirow{3}{*}{ OSORS } & Átfogó & 0,85 & 3,13 & 0,71 \\
\hline & Probléma-megoldó & 0,80 & 3,43 & 0,66 \\
\hline & Olvasást támogató & 0,75 & 2,82 & 0,74 \\
\hline
\end{tabular}

2. táblázat: Reliabilitás, átlag és szórás a nyelvtanulási stratégiák és online olvasási stratégiák kérdőivek kategóriáiban

Ezt követően elemeztük a résztvevők nyelvtanulási stratégiahasználatát. Az eredmények mérsékelt stratégiahasználatot mutattak majdnem minden kategória esetében. Az affektív stratégiák használata szignifikánsan alacsonyabb stratégiahasználatot jelzett $(t=62,67 ; p<0,001)$. A hallgatók a metakognitív stratégiáikat használták szignifikánsan a leggyakrabban $(t=64,34 ; p<0,001)$. Az online olvasás területén a problémamegoldó stratégiatípus volt a szignifikánsan leggyakrabban alkalmazott ( $t=81,31 ; p<0,001)$, míg az olvasást támogató stratégiák a szignifikánsan legritkábban használt stratégiák voltak ( $t=59,80 ; p<0,001)$, azonban ebben az esetben is mérsékelt szintú stratégiahasználat a jellemző. Összességében a mintát leginkább a metakognitiv és a problémamegoldó stratégiák használata jellemzi.

\section{Összefüggés-vizsgálatok}

Összefüggés-vizsgálatokkal kerestünk választ arra, hogy a kérdőívek által vizsgált változók között felfedezhetőek-e szignifikáns összefüggések. A Pearson-féle korreláció eredményei szerint a nyelvtanulási stratégiák területei között szignifikáns kapcsolatok mutatkoztak. Minden esetben szignifikáns összefüggéseket találtunk ( $r$ $=0,74-0,21$; lásd 3. táblázat). A legerősebb összefüggéseket a metakognitív és a szociális $(r=0,74)$, a metakognitiv és a kognitív $(r=0,70)$, valamint a kognitiv és a szociális $(r=0,67)$ stratégiahasználatok között regisztráltuk. Ehhez hasonlóan az online olvasási stratégiák területén is minden esetben erős szignifikáns kapcsolatot találtunk, a korrelációs együtthatók $r=0,76-0,64$ között mozogtak. A két kérdőív területeinek kapcsolata is minden esetben szignifikáns összefüggést jelzett. A legmagasabb korrelációs együttható a kognitiv és a problémamegoldó $(r=0,45)$, a memória és az átfogó $(r=0,38)$, valamint a memória és a problémamegoldó $(r=0,37)$ stratégiák között tárható fel. 


\begin{tabular}{lllll|lllll} 
Kategóriák & 1. & 2. & 3. & 4. & 5. & 6. & 7. & 8. & 9.
\end{tabular}

\begin{tabular}{|c|c|c|c|c|c|c|c|c|}
\hline 1. Mem. & 1 & & & & & & & \\
\hline 2. Kog. & $0,56^{* *}$ & 1 & & & & & & \\
\hline 3. Kom. & $0,29^{* *}$ & $0,53^{* *}$ & 1 & & & & & \\
\hline 4. Mk. & $0,53^{* *}$ & $0,70^{* *}$ & $0,28^{* *}$ & 1 & & & & \\
\hline 5. Aff. & $0,29^{* *}$ & $0,32^{* *}$ & $0,21^{* *}$ & $0,42^{* *}$ & 1 & & & \\
\hline 6. Szoc. & $0,48^{* *}$ & $0,67^{* *}$ & $0,30^{* *}$ & $0,74^{* *}$ & $0,41^{* *}$ & 1 & & \\
\hline 7. Átf. & $0,38^{* *}$ & $0,31^{* *}$ & $0,30^{* *}$ & $0,25^{* *}$ & $0,23^{* *}$ & $0,25^{* *}$ & 1 & \\
\hline 8. Prob. & $0,37^{* *}$ & $0,45^{* *}$ & $0,32^{* *}$ & $0,34^{* *}$ & $0,20^{* *}$ & $0,35^{* *}$ & $0,76^{* *}$ & 1 \\
\hline 9. Ot. & $0,37^{* *}$ & $0,16^{*}$ & $0,23^{* *}$ & $0,15^{*}$ & $0,27^{* *}$ & $0,14^{*}$ & $0,71^{* *}$ & $0,64^{* *} \quad 1$ \\
\hline
\end{tabular}

3. táblázat: A nyelvtanulási stratégiák és az online olvasásistratégia-használat közötti összefüggések. 1. Memória, 2. Kognitív, 3. Kompenzáló, 3. Metakognitív, 5. Affektív, 6. Szociális, 7. Átfogó, 8. Problémamegoldó, 9. Olvasást támogató ${ }^{* *} p<0,01 ;{ }^{*} p<0,05$

Kutatásunk harmadik kérdésének megválaszolására strukturális modellt állítottunk fel. Előző kutatások feltárták, hogy a nyelvtanulási stratégiák között szignifikáns kapcsolat található (Habók \& Magyar, 2018a), valamint az olvasás során használt stratégiák között is felfedezhető kapcsolat (Habók \& Magyar 2019; Habók, Magyar \& Nagy-Pál, 2018). Ebből kiindulva feltételeztük, hogy ezek a stratégiák nem különülnek teljesen el, hanem egymásra is hatással vannak. Modellünkben a nyelvtanulási stratégiák online olvasási stratégiákra gyakorolt hatásából indultunk ki, ezért feltételezett modellünk független változójának a nyelvtanulási stratégiákat tekintettük, és ezek hatását vizsgáltuk az online olvasási stratégiákra mint függő változóra. Miután meg vizsgáltuk, hogy a feltételezett modellünk múködőképes-e (4. táblázat), az eredmények arra mutattak rá, hogy az egydimenziós modellünk (1. ábra) nem működőképes. Ez arra hívta fel a figyelmet, hogy a stratégiák diffe renciáltabb vizsgálatára van szükség. Ezért feltártuk, hogy melyik az az optimális struktúra, melynek segítségével leírható a stratégiák egymásra gyakorolt hatása.

\section{Nyelvtanulási stratégiák}

\section{Online olvasási statégiák}

1. ábra: Az egydimenziós modell. 


\begin{tabular}{|lll|c|ccccc}
\multicolumn{1}{r}{ Modell } & \multicolumn{1}{c}{ Chi-square } & df & $\mathbf{p}$ & CFI & TLI & NFI & RMSEA \\
\hline Egydimenziós & 0,000 & 0 & m.d. & 1,000 & m. d. & 1,000 & 0,404 \\
Többdimenziós & 18,795 & 12 & 0,094 & 0,994 & 0,977 & 0,984 & 0,048
\end{tabular}

4. táblázat: A feltételezett modellek illeszkedésmutatói, m. d. = missing data, hiányzó adat

Többdimenziós modellünk (2. ábra) CFI, TLI és NFI értékei minden esetben a 0,95-ös határ felett voltak, míg RMSEA értéke 0,06 alatt alakult, és ezzel jól illeszkedő modellstruktúrát jelzett (Kline, 2015) (4. táblázat).

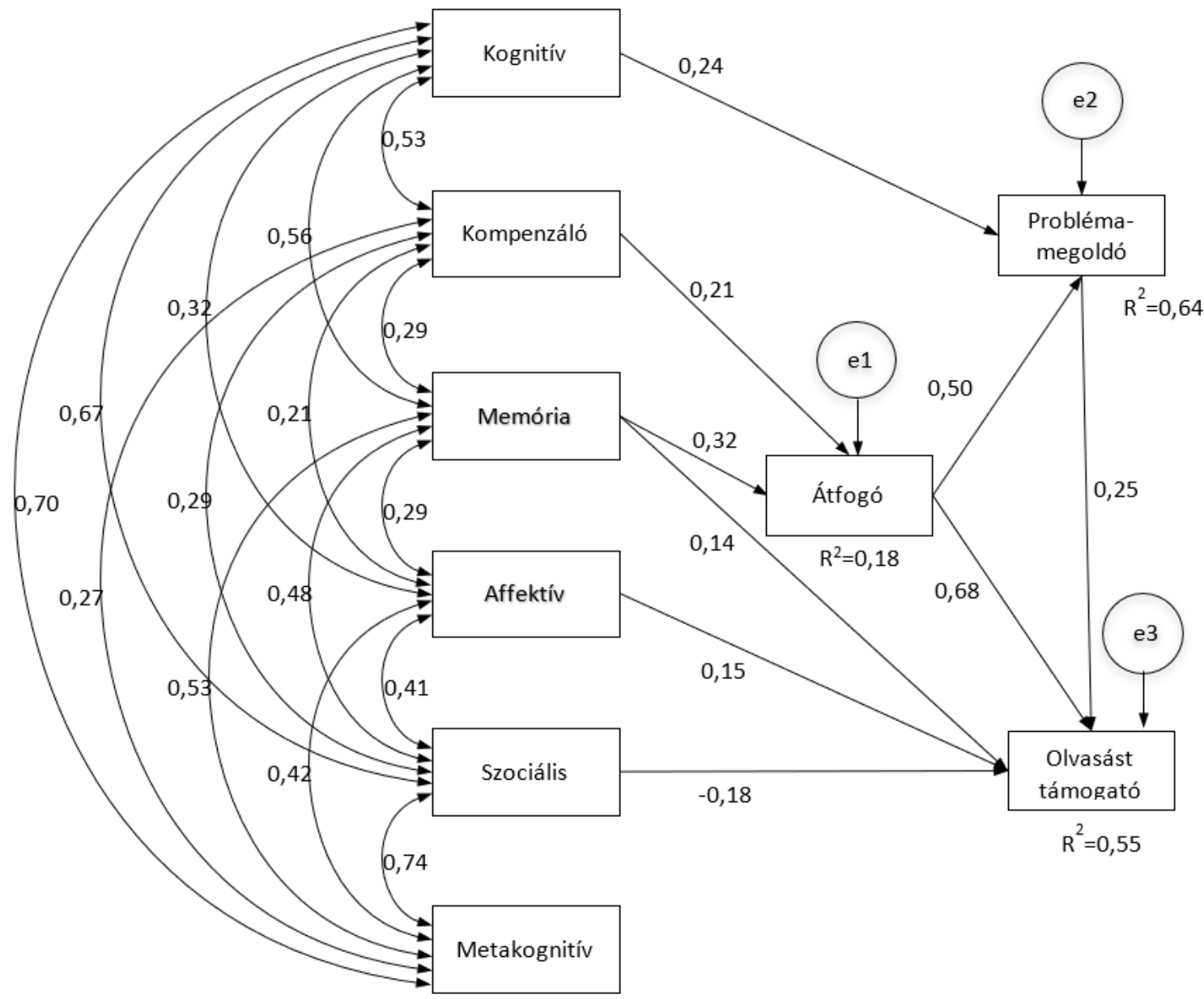

2. ábra: A többdimenziós modell szerkezete $(p<0,05)$

\section{Az eredmények értelmezése}

Vizsgálatunk két kutatási területet ölel fel. Egyik a nyelvtanulási stratégiák vizsgálata az angol mint idegen nyelvre vonatkozóan, a másik az online olvasási stratégiák alkalmazása az angol nyelv használatához kapcsolódóan egyetemi tanárszakos hallgatók körében. A két kutatási terület közös pontja a nyelvtanulási stratégiák használatának hatása az online olvasási stratégiák alkalmazására. A kutatási eredményeink a nyelvtanulási stratégiák esetében a metakognitív stratégiák domináns használatát mutatták. Ezek az adatok összhangban vannak korábbi eredményekkel, mely általános iskolás tanulók kérdőíves mérését állították a középpontba. Habók 
és Magyar (2018a) magyar mintán, Dawadi (2017), Radwan (2011) és Wu (2008) nemzetközi kontextusban szintén a metakognitív stratégiák domináns használatát találták. A második leggyakrabban alkalmazott stratégia a kognitív nyelvtanulási stratégia volt, amelynek domináns hatását szintén több kutatás megerősíti (Wu, 2008; Al-Qahtani, 2013). A metakognitív stratégiák ahhoz járulnak hozzá, hogy a nyelvtanuló úgy tudja szervezni a nyelvtanulását, hogy elérje a célját, jobb és sikeresebb nyelvtanulóvá váljon. A kognitiv stratégiák magára a tanulási folyamatra vonatkoznak, konkrétan az ismeretek feldolgozásának mikéntjét támogatják. Ez a két stratégiatípus segíti tehát legkonkrétabban az idegennyelv-tanulás folyamatát, talán ezért a leggyakrabban alkalmazott stratégiatípus.

Az online olvasási stratégiák közül a problémamegoldó stratégiák használata volt a leggyakoribb hasonlóan több, más kutatási eredményhez (Anderson, 2003; Omar, 2014; Jusoh \& Abdullah, 2015; Ahmadian \& Pasand, 2017). A második leggyakoribb az átfogó stratégiahasználat volt Ahmadian és Pasand (2017) kutatásához hasonlóan, és a magyar mintához hasonlóan az olvasást támogató stratégiák kevésbé preferált választását állapították meg. A problémamegoldó stratégiák magasabb arányú használatát az jelzi, hogy a nyelvtanulók online olvasás közben folyamatosan próbálják követni a gondolatsort, amennyiben nem értik a szöveget, lelassítanak, és újra elolvassák, értelmezik azt. Az átfogó stratégiák abban segítenek, hogy a nyelvtanuló aktiválja az általános tudását, mozgósítsa előzetes ismereteit, vagy először fussa át a szöveget. Ezeket a stratégiákat viszonylag könnyű alkalmazni, eltérően a harmadik típustól, az olvasást támogató stratégiáktól, amelyek különböző kiegészítő segítséget, jegyzetkészítést, szótárhasználatot, illetve nyomtatást igényelnek. Ez lehet a támogató stratégiák alacsonyabb szintú használatának a magyarázata.

Az összefüggés-vizsgálatok megerősítették azt a hipotézisünket, hogy a különböző nyelvtanulási és olvasási stratégiák között szignifikáns kapcsolatok vannak. A hatások tekintetében a felépített modell alapján elmondható, a nyelvtanulási stratégiák összességében nem, azonban bizonyos faktoraik szignifikáns hatást gyakorolnak az online olvasási stratégiahasználatra. A többdimenziós modell szerint a nyelvtanulási stratégiák közül a metakognitiv nyelvtanulási stratégiák nem határozzák meg közvetlen módon az online olvasási stratégiákat. A kapott modell eredményei arra világítottak rá, hogy a legerősebb közvetlen hatása a memória stratégiáknak van az átfogó olvasási stratégiákra, azonban a kompenzáló stratégiák hatása is viszonylag erős az átfogó olva sási stratégiákra. A kognitiv stratégiák problémamegoldó stratégiákra gyakorolt közvetlen hatása is szignifikáns. A memorizáló és az affektív stratégiák szignifikáns, de alacsonyabb hatását találtuk az olvasást támogató stratégiákra nézve. A szociális stratégiák negatív hatása mutatkozott az olvasást támogató stratégiákra. A közvetett hatások esetében megfigyelhető a kompenzáló és a memorizáló stratégiák hatása az átfogó olvasási stratégiákon keresztül a problémamegoldó, illetve olvasást támogató stratégiákra, mint ahogyan a memorizáló, az affektív és a szociális stratégiák közvetett hatása is kimutatható az olvasást támogató stratégiákon keresztül a problémamegoldó stratégiákra. Összességében a nyelvtanulási stratégiák közül a memória, a kompenzáló és a kognitív stratégiák hatása a legjelentősebb, és az átfogó olvasási stratégiák központi szerepe figyelhető meg.

\section{A kutatás korlátai}

A kutatásunk korlátait a következő szempontok alapján határozhatjuk meg. Először is, mivel a hallgatói részvétel önkéntes volt, így előfordulhat, hogy azon hallgatók szolgáltattak adatot, akik elkötelezettebbek tanulásuk és tanulási sikerük iránt. Másodszor, a kérdőív kitöltése önbevalláson alapult, így nincs módunk ellenőrizni, hogy a hallgatók tanulási sikere ténylegesen megvalósul-e, és valóban magas szinten használják-e a bejelölt stratégiákat. Harmadszor, a minta csekély arányától eltekintve, tanulnak a kutatásban résztvevők másik idegen nyelvet is. Felmerül a kérdés, hogy az idegen nyelvi stratégiákat mennyire tudják elkülöníteni, vannak-e specifi- 
kus, csak az angol nyelv tanulásához használt stratégiáik. Negyedszer, felmerül a kérdés, hogy az online olvasás és a közben használt stratégiák mennyiben jelennek meg az online tanulás során, vagy csak szabadidős tevékenységekhez kapcsolódnak-e.

\section{Kitekintés}

A kutatásunk számos eredménnyel szolgál a nyelvtanulás és az online tanulás kutatásához. Először is kutatásunk megerősítette a stratégiák tanításának fontosságát, melyek használata az önszabályozott tanulás lényeges eleme. Másodszor felhívta arra a figyelmet arra, hogy a tantárgyspecifikus stratégiahasználat az online tanulásra is hatást gyakorol.

\section{Köszönetnyilvánítás}

A tanulmány írása alatt Habók Anita Bolyai János Kutatási Ösztöndíjban részesült.

\section{Irodalom}

1. Ahmadian, M. \& Pasand, P. G. (2017). EFL learners' use of online metacognitive reading strategies and its relation to their self-efficacy in reading. The Reading Matrix, 17(2), 117-132.

2. Al-Qahtani, M. F. (2003). Relationship between English language, learning strategies, attitudes, motivation, and students' academic achievement. Education in Medicine Journal, 5(3), 19-29. https://doi.org/10.5959/eimj.v5i3.124

3. Anderson, N. J. (2003). Scrolling, clicking, and reading English: Online reading strategies in a second/foreign language. The Reading Matrix, 3(3), 1-33.

4. Cho, B. Y. \& Afflerbach, P. (2017). An evolving perspective of constructively responsive reading comprehension strategies in multilayered digital text environments. In Handbook of research on reading comprehension (pp. 109-134). New York: Guilford Press.

5. Coiro, J. (2012). The new literacies of online reading comprehension: Future directions. The Educational Forum, 76(4), 412-417. http://dx.doi.org/10.1080/00131725.2012.708620

6. Coiro, J. \& Dobler, E. (2007). Exploring the online reading comprehension strategies used by sixthgrade skilled readers to search for and locate information on the Internet. Reading Research Quarterly, 42(2), 214-257.

7. Dawadi, S. (2017). Language learning strategies profiles of EFL learners in Nepal. European Journal of Educational and Social Sciences, 2(2), 42-55.

8. Doró, K. \& Habók, A. (2013). Language learning strategies in elementary school: the effect of age and gender in an EFL context. Journal of Linguistics and Language Teaching, 4(2), 25-37.

9. Doró, K., Habók, A. \& Magyar, A. (2018). Nyelvtanulási stratégiák tanítása és fejlesztése. Budapest: Akadémiai Kiadó.

10. Dörnyei, Z. (2005). The Psychology of the Language Learner: Individual Differences in Second Language Acquisition. Mahwah: Lawrence Erlbaum Associates.

11. Grabe, W. (2009). Reading in a second language: moving from theory to practice. New York: Cambridge University Press.

12. Habók, A. \& Magyar, A. (2018a). The effect of language learning strategies on proficiency, attitudes and school achievement. Frontiers in Psychology, 8, 2358. 1-8. DOI: 10.3389/fpsyg.2017.02358

13. Habók, A. \& Magyar, A. (2018b). Validation of a self-regulated foreign language learning strategy questionnaire through multidimensional modelling. Frontiers in Psychology, 9, 1388. 1-9. DOI: 10.3389/fpsyg.2018.01388 
14. Habók, A. \& Magyar, A. (2019). The effects of EFL reading comprehension and certain learning-related factors on EFL learners' reading strategy use, Cogent Education, 6(1), 1616522, 1-19. DOI: 10.1080/2331186X.2019.1616522

15. Habók, A., Magyar, A. \& Nagy-Pál, M. (2018). 10-14 éves tanulók idegen nyelvú szövegértési, szövegalkotási tudásának és stratégiahasználatának vizsgálata, Neveléstudomány, 1(1), 60-77. DOI: 10.21549/NTNY.21.2018.1.4

16. Jusoh, Z. \& Abdullah, L. (2015). Online survey of reading strategies (OSORS): Students' online reading in academic context. Malaysian Journal of Distance Education, 17(2), 67-81. DOI: 10.21315/mjde2015.17.2.5

17. Kline, R. B. (2015). Principles and practice of structural equation modeling. New York: Guilford Press. Available https://www.guilford.com/books/Principles-and-Practice-of-Structural-EquationModeling/Rex-Kline/9781462523344

18. Magyar, A., \& Habók, A. (2018). Olvasási stratégiák vizsgálata angol nyelvű szövegértési feladatokban 10-14 éves nyelvtanulók körében. Iskolakultúra, 28(8-9), 22-37. DOI: 10.17543/ISKKULT.2018.8-9.22

19. Mokhtari, K. \& Sheorey, R. (2002). Measuring ESL students' awareness of reading strategies. Journal of Developmental Education, 25(3), 2-10.

20. Omar, N. A. (2014). Online metacognitive reading strategies use by postgraduate Libyan EFL students. World Academy of Science, Engineering and Technology. International Journal of Social, Behavioral, Educational, Economic, Business and Industrial Engineering 8(7), 2289-2292. DOI: 10.5281/zenodo.1093956

21. Oxford, R. L. (1990). Language learning strategies: What every teacher should know. Boston, MA: Heinle and Heinle.

22. Oxford, R. L. (2003). Language learning styles and strategies: An overview. Proceedings of GALA (Generative Approaches to Language Acquisition) conference, 1-25.

23. Oxford, R. L. (2017). Teaching and researching language learning strategies: Self-regulation in context. New York, NY: Routledge.

24. Poole, A. (2010). The reading strategies used by male and female English language learners: A study of Colombian high school students. New England Reading Association Journal, 46(1), 55-63.

25. Radwan, A. A. (2011). Effects of $L 2$ proficiency and gender on choice of language learning strategies by university students majoring in English. Asian EFL Journal, 13(1), 115-163.

26. Rubin, J. (1975). What the "good language learner" can teach us? TESOL Quarterly, 9(1), 41-51. DOI: $10.2307 / 3586011$

27. Takallou, F. (2011). The effect of metacognitive strategy instruction on EFL Learners' reading comprehension performance and metacognitive awareness, Asian EFL Journal, 13(1), 272-300.

28. Tseng, W., Dörnyei, Z. \& Schmitt, N. (2006). A new approach to assessing strategic learning: the case of self-regulation in vocabulary acquisition. Applied Linguistics, 27(1), 78-102. DOI: 10.1093/applin/ami046

29. Wu, Y. L. (2008). Language learning strategies used by students at different proficiency levels, Asian EFL Journal, 10(4), 75-95. DOI: 10.5539/ijel.v1n2p203 


\section{Correlations between English Language Learning and Online Reading Strategy Use of Preservice Teachers}

Nowadays, foreign language learning and acquiring, and obtaining information in foreign language often take place on the online platform, which requires that language learners possess the appropriate level of foreign language reading skills and online reading strategies needed to interpret and process information available in a foreign language. The aim of our research is to map the extent to which university students use their online reading strategies to help them obtain a variety of information in the digital space, and we have also investi gated the relationship between students' use of language learning strategies and online reading strategies. Oxford's (1990) Strategy Inventory for Language Learning (SILL) questionnaire was applied to measure the use of language learning strategies, and Anderson's (2003) Online Survey of Reading Strategies (OSORS) questionnaire was used to examine online reading strategies. The results indicated moderate strategy use for both questionnaires. Of the language learning strategies, the use of metacognitive strategies was the most common, while of the online reading strategies, the problem-solving strategy type was the most commonly employed. We detected significant relationships among the language learning and reading strategies in every case, and our results confirmed the functionality of our multidimensional model, which presumed that language learning strategies as a whole do not have, but certain factors exert significant impact on online reading strategy use. Among language learning strategies, the effects of memory, compensatory, and cognitive strategies were the most significant, and comprehensive reading strategies played central role in the process. Our research drew attention to the importance of teaching strategy use.

Keywords: language learning strategies, online reading, questionnaire, model development 